\title{
THE SANTA CASA DA MISERICÓRDIA OF LISBON.
}

\section{MANOEL DA SILVEIRA CARDOZO}

The Catholic University of America (USA).

To the Portuguese of the Counter-Reformation, nothing was more important than the salvation of the soul, and the world, over which Satan exerted an excessive dominion, was meaningful only because God afforded man the grace to avoid temptation and the chance of redeeming himself. The spiritual tone of those Baroque years was directed by the triumphal Church of the Council of Trent, but it was not an innovative departure from habitual Portuguese spirituality. Dom Jaime, Duke of Bragança, had already expressed it well in 1530 when he declared that what he prized most was the welfare of his soul (1).

The spectre of Hell was always before them, in sin as in moments of spiritual euphoria, the realization that evil men who died unconfessed and unrepentant were doomed to a "furnace of fire" where every limb, every vein, nerve, tendon, muscle, cartilage, the eyes, the ears, the nose, the mouth, the throat, the heart, the brain, the marrow itself would exhale and spew fire forever (2). To escape perdition and achieve salvation involved faith in the providence of God but it also required an effort on man's part, a dedication to prayer, fasting, and almsdeeds. Faith was "the beginning, the foundation, and the root of all Justification". The Fathers of Trent had said so. But man

(1). - The Duke of Bragança to Dom António de Ataíde, Vila Viçosa, December 12, 1530, in J. D. M. Ford and L. G. Moffatt, Letters of the court of John III king of Portugal. The Portuguese Text, Edited with an Introduction (Cambridge, Mass., 1933), p. 89.

(2). - Alexandre Perier, Desengano dos peccadores, necessario a todo genero de pessoas, utilissimo aos missionarios, e aos Prégadores desenganados, que só desejão a salvação das Almas (Lisboa, 1735), p. 19. 
was not justified, as Luther believed, contrary to Holy Writ and tradition, as Catholics believed, by faith alone. Justification was by faith and good works.

"If any one shall say that the wicked man is justified by faith alone, meaning that no other thing is required to co-operate for obtaining the grace of justification, and that it is not necessary for him to be prepared and disposed by the movement of his will, let him be anathema" (3).

The clergy from the pulpit and in the confessional, the moralists in their writings harped constantly on the merit of works of mercy, and the living forces of Baroque society pressured the faithful to practice them. There was no question about knowing what to do. TheoIngians and catechists had long since identified them, and the Christian had long since committed them to memory, fourteen in all, seven spiritual, seven corporal. Spiritual works meant converting sinners, instructing the ignorant, counseling the redeless, comforting the sorrowing, bearing ills patiently, forgiving wrongs, and prayer for the quick and the dead. Corporal works, feeding the hungry, refreshing the thirsty, clothing the naked, sheltering the homeless, tending the sick, visiting the imprisoned, and burying the dead.

The Tridentine concern for good works coincided in Portugal, for the most part, with the overseas expansion of the nation, and the accumulation of wealth that resulted from it made it possible for the Portuguese to achieve, during the Age of the Baroque, in the practice of charity, lovely and unparalleled heights. No other nation in Europe, a sympathetic foreigner observed in 1814, when the Baroque experience was on the verge of being spent, was "more hospitable or more compassionate than the Portuguese", and no city "more universally, and more constantly" practiced "this sublime virtue, this virtue which may be called a religious duty" than Lisbon (4).

In the city of Lisbon, by 1600 the vital center of an empire that extended in sovereignty or in influence from South America to the Spice Islands and Japan, works of mercy during the Baroque period were performed by individuals or collectively by duly-constituted corporations. Some individuals were of the towering stature of the Lord Chancellor of Portugal, Inácio Ferreira, whose manifold works of mercy, before his death in 1629 , were proverbial in his own day. He looked after the proud poor with discretion and without embarrassment.

(3). - Siss. VI, can. 9, de iustificatione.

(4). - Henry L'Evêque, Portuguese Costumes (London, 1814). 
He fed the poor every day with food from his kitchen, and on some days of the week the imprisoned. What he spent for charity exceeded what he earned, yet he managed with the "particular favor of Heaven" to persevere until the end (5). Another pious man, António José de Miranda Henriques, son of Diogo de Mendonça Corte-Real, the Secretary of State, served dinner to 13 poor men and 1 poor woman every Friday of the year (6). Still a third kind of charity, triumphant and magnificent, was represented by the Church of the Incarnation, still standing in Lisbon on the south side of the Largo do Chiado facing the eighteenth-century church of the Italian Nation, built by a merciful widow, Dona Elvira Maria de Vilhena, Countess of Pontivel, between 1698 and 1708 (7).

Rel:gious communities everywhere, monasteries, convents, nunneries, colleges, and houses of study, were known for their charity, and often served as dispensaries for the poor. This was also true of the military orders. The rule of the Order of Avis, published in 1631, made the feeding of the needy a duty of the Lisbon community. Food left over in the refectory after the mid-day meal was to be distributed among the Convent's regular poor at the doorkeeper's lodge. On Maunday Thursday, the Convent was bound to give a "hearty dinner" to these poor, and on the Fridays of Lent and again on Maunday Thursday, professed members of the community were to take food to the imprisoned (8).

Last wills and testaments during the Baroque period, which normally disposed of material things as also of matters that involved the soul, were an especially significant source of good works. The notarial archives of Portugal are filled with wills that spelled out on the practical level, the meaning of piety and mercy. They were used by some to disclose secrets of life: an illegitimate child, family quarrels, personal piques. Money and chattel owed and due were often listed. Hurts were forgiven, pardon implored of persons offended. King John IV (1640-1656) used his will to ask the nation to forgive the faults of

(5). - José Barbosa, Memorias do Collegio Real de S. Paulo da Universidade de Coimbra, $e$ dos seus collegiaes, e porcionistas, Offerecidas a elrey nosso senhor $D$. João o V (n. p., n. d.). p. 96.

(6). - Arquivo Nacional da Torre do Tombo, Registro Geral de Testamentos, $L^{\circ}$ 200, fol. $143 \mathrm{v}$. The will is dated Lisbon, August 21, 1724.

(7). - Cristóvão Rodrigues de Oliveira, Summario, em que brevemente se contem algumas cousas assim Ecclesiasticas. como Seculares, que ha na Cidade de Lisboa (Lisboa, 1755), p. 131. The book includes a supplement by Manoel da Conceição, the editor, covering the years 1551-1754.

(8). - Regra da cavallaria e ordem militar de $S$. Bento de Av's (Lisboa, 1631), fol. $91 \mathrm{v}$. 
his government. He had not done wrong through intention. And God knew what a cross he had to bear when he accepted the Crown. He accepted it because learned men told him that he was in conscience bound to accept a natural inheritance that was freely offered (9).

The Portuguese had no morbid attraction for death, and did not look forward to it.

"... the nearness, and thought of death", as Amador Arrais, Bishop of Portalegre, wrote in his Diálogos of 1589, "seriously displeases, and torments us, and ... there is nothing more terrible, and sadder for man, than to separate himself from this life" (10).

Yet a responsible man prepared for the end, and the eve of death was faced by Christians with fortitude, and accepted as a time to thank people for their favors, slaves and servants for their fidelity and dedication. Time to perform, through the instrumentality of executors and the protection of the law, final works of charity, or carry out charitable enterprises that in life were not carried out. The last opportunity to manumit a slave, reward a servant, remember a neighbor. To provide oil for chapel lamps, wax candles for altars, stipends for masses for one's immortal soul or for the most abandoned souls in Purgatory. Bequests, in some instances, made in perpetuity, until the end of time, reflecting the assurance of stability of a society that nobody believed would be disturbed or overthrown. Wills, in short, that took the sting out of death and gave man another chance to right himself with God.

There were many kinds of wills, depending on one's condition and state of life, but the concerns they reflected were basically the same. The concerns, for example, of the first bishop of Mariana, who departed this life in 1764, earmarking 200 drams of gold to be distributed among the first 400 poor mourners who gathered at his doorkeeper's lodge, another 200 to the Brotherhood of the Sacred Hearts of Jesus, Mary, and Joseph to be used for the neediest poor, 20 drams for the poor who every month had received alms at the Bishop's House. He remembered a House of Retirement in Minas Gerais, special charities in Lisbon. Not a single tostoon was left to a relative or member of his immediate family. The residuary estate was intended to be divi-

(9). - Francisco Leitão da Silva, Relaçam da morte, e enterro da magestade serenissima delrey $D$. Ioam o IV de glorioza memoria (Lisboa, 1656), A4.

(10). - Amador Arrais, Dialogos (Coimbra, 1589), fol. 137. 
ded equally among the widowed poor of the diocese, the diocesan seminary, and the House of Retirement (11).

Fernando de Oliveira left a sum of money in 1732 for 5,500 masses for the repose of his soul (12). António Coelho Brás Teles de Meneses Miranda Lobo Beja de São Paio, a rich bachelor with a string of aristocratic names, willed his estate to his soul, the Baroque way of saying, when there were no "forced heirs", that his goods would be used for spiritual and corporal works of mercy (13). Dona Máxima Teresa de Albuquerque, wife of José da Cunha Brochado, left a pot of oil to a chapel in the Paulist Church of Lisbon (14). Dom Rodrigo da Silveira Silva Teles, Count of Sarzedas, asked to be buried with austerity, believing it vain to pay honor "to a body often already fetid, and soon to return to dust" (15): A justice of the House of Supplication, the ultimate court of law, freed his slave, left him clothes and bedding, and a legacy to provide for his other needs. His way of thanking him and his mother for their "love and faithfulness". From beyond the grave, he entreated the slave to live worthily and "to pray to God Our Lord for me" (16).

Another testator left funds for a mass to be said for his soul on the first day of every month at the altar and chapel of Our Lady of Agonizants of the Church of São Roque (17). The income from the residue of the estate would be distributed "to the end of the world", one year for dowries for poor females, one year for alms and pious works (18). Manuel Leal, a wealthy business man, left a bequest in his will of 1726 for masses to be said for the souls of persons who might have suffered losses from the commercial dealings they had had with him, another bequest for clothing for the incurables of the Hospital of Nossa Senhora do Amparo. In a touching moment of friendship, he instructed his grandson, Dr. Manoel Pereira da Silva, to call at the Palace to ask the chamberlain on duty to inform His Majesty of his

(11). - Raimundo Trindade, Archidiocese de Marianna. Subsidios para a sua historia, I (São Paulo, 1928), 178.

(12) . - Arquivo Nacional da Torre do Tombo, Registo Geral de Testamentos, $L^{\circ} 200$. His will is dated Lisbon, June 2, 1732.

(13). - Arquivo Nacional da Torre do Tombo, Registo Geral de Testamentos, $L^{\circ} 200$, fol. 154 verso. His will is dated Lisbon, October $21,1729$.

(14). - Will of March 7, 1726, in Arquivo Nacional da Torre do Tombo, Registo Geral de Testamentos, L 183 , fol. 126.

(15). - Will of March 1, 1726, in loc. cit., Lo 195, fol. 79.

(16). - Will of Desemibargador Lopo Tavares de Ar.9 [?], Lisbon, October 23,1722 , in loc. cit., $L^{\circ} 195$, fol. 100.

(17). - Ibid., fol. 103 .

(18). - Ibid., fol. $103 \mathrm{v}$. 
death, and to beg the King's forgiveness for any shortcoming (19). António Francisco Fialho, a storekeeper. declared in his will of 1730 that through God's mercy he would expiate his sins in Purgatory. He left money for dowries for 10 orphan girls of good repute, other money to buy clothing for poor widows, 10 from the parish of Our Lady of the Immaculate Conception and 10 from São Julião, additional money to the Royal Hospital for poor patients and foundlings, still other funds to provide clothing for the poor of the Hospital for Incurables and to help the poor serving sentences in Limoeiro Jail (20). Tomás de Carvalho de Faria, a native of Bahia, declared in 1733 that he was engaged to marry Antónia Joaquina de Melo of Lisbon and that her unborn child was his (21). Francisco Pinheiro, by his will of 1749 , instituted life endowments for four poor women of good repute to assist daily at two masses for the souls of the testator and his wife (22).

"... the death of the pious", Amador Arrais believed, "is joyful, quiet, and peaceful" (23), but the achievement of the state of mind that he admired through the practice of good works, when it extended beyond the grave, created situations that he had already questioned. When times were hard and life unbearable, when honest maidens were sold to the highest bidder, when widows suffered, the married were pressed to feed their children, hospitals were short of beds, and prisoners languished in jail because they were penniless, what could the justification have been for endowments that would provide for the poor yet unborn when the living destitute were abandoned? (24).

In 1769, when it abolished the lavish practice of the Portuguese of endowing masses, the Crown and the Marquess of Pombal surely did not think as Arrais thought in the sixteenth century, the exclamation of an outraged moralist pointing up forgotten areas of charitable concern. The Crown was not concerned about the dispossessed but about the viability of the economy, for if the pious custom had been allowed to continue the "souls of the other World" would have ended

(19). - Will of January 24, 1726, in Arquivo Nacional da Torre do Tombo, Registo Geral de Testamentos, L9 195, fol. 159-160 v.

(20). - Will of April 16, 1730, in loc. cit., L9 200, fol. 167 v. -169 v.

(21). - Will of December 6, 1733, in loc. cit., Lo 204 , fol. $100 \mathrm{v}$.

(22). - Will of June 22, 1749, in "Documentos diversos relativos ao Hospital 1575 a 1749 numero 1", Arquivo Histórico do Hospital de São José, no. 1139 , fol. 98 .

(23). - Arrais, op. cit., fol. 146.

(24). - Ibid., fol. 208. 
up owning "all the Property of the Kingdom..." (25). By 1769 the accumulation of mass charges had reached such a level that even if everyone in Portugal were a cleric not even a third of the masses provided for by will could have been said. In one of the smallest Provedorias of the realm, 12,000 mass endowments and more than 500,000 annual masses were registered (26). The restrictions were reinforced in 1796, during the reign of Dona Maria I, when a man's estate could not thenceforth be left to his soul (27).

The action of the Crown, coming at a time when the Baroque ethic was being progressively weakened, made light of the propensity of the Portuguese for pious works, more than that, the two measures were flagrant examples of the spirit of secularism and irreligion that began to affect the highest levels of Portuguese society during the second half of the eighteenth century. Would the solutions of 1769 and 1796 to a situation that admittedly had got out of hand have been possible in earlier, more religious times?

Actually, there existed a tribunal or board, the Mesa da Consciência e Ordens, a sensitive part of the administrative machinery, that had been set up in the first place to deal precisely with such problems, but it is not important in this context to know whether or not it was asked for its opinion before the promulgation of the restrictive laws of 1769 and 1796. The Board itself was of ancient lineage, having been founded by King John III in 1532, and it was designed to handle problems of a moral order that taxed the conscience of Christians and more particularly the pious and religious sovereign whose business it was to resolve them. Until its extinction in 1833 , the Board played a greater or lesser role in the administration of works of mercy.

The Board became involved in time with the affairs of the three military orders of Christ, Avis, and Santiago, and its title was correspondingly enlarged to include its new responsibilities. This remarkable Mesa, an integral and special part of the Baroque way of life, was unique in Europe. No Christian monarch anywhere, as the Board itself recognized in 1644, with the single exception of the King of

(25). - Collecção das leys, decretos, e alvarás, que comprehende o feliz reinado del rey fidelissimo $D$. José o $I$. nosso senhor Desde o anno de 1761 até $o$ de 1769, I (Lisboa, 1793), carta de lei of September 9, 1769.

(26). - Ibid.

(27). - Manuel Borges Carneiro, Direito civil de Portugal, contendo tres livros: I. das pessoas, II. das cousas, III. das obrigações e aç̧ões, I (Lisboa, 1851), 60 . 
Portugal, was ever concerned enough about qualms of conscience to have done what he did (28).

According to the statutes of August 23, 1608, the Board's authority and jurisdiction covered everything involving the Superintendency of Captives and all other matters dealing with the ransoming of Portuguese fallen into the hands of infidels and enslaved (29). It covered the administration and supervision of the orphanages of Lisbon, marriage dowries from the proceeds of endowments, and masses that by testament were required to be said but were not said. The Board managed the chapels and prayer endowments founded and instituted by King Afonso IV (1325-1357) and by his wife, Dona Brites of Castile, in the city of Lisbon. The prayer endowments of Queen Catherine, wife of John III (1521-1557), and of the King's brother, the Infante Dom Luís, in the Monastery Church of Belém. The prayer endowments of Queen Dona Leonor, wife of John II (1481-1495), in Cbidos, Torres Vedras, Alenquer, and the Monastery of the Trinity of Lisbon. It supervised the Hospital of Caldas da Rainha, founded by Queen Dona Leonor, the first in Europe built to make use of mineral waters, and other hospitals, leprosaria, and asylums under royal protection, except the Royal Hospital of All Saints of Lisbon, which was under other auspices. The Board's concerns were never too minor or personal. When the Queen Regent in 1565 wanted to know whether or not it was licit to fish for tuna in the Algarve on Sundays and Holy Days of Obligation, the Mesa laid to rest Her Majesty's scruples (30). Again, when the Dutch took Bahia in 1624, they arrested 12 Jesuit priests, shipped them to Holland, and kept them in jail for two years until they were able to ransom their freedom for 1,000 cruzados. Upon their return to Portugal, the victims of Dutch intolerance asked for reimbursement from funds set aside for the redemption of captives in North Africa, but the Board refused (31).

The Board of Conscience had nothing to do with another charity founded by Queen Dona Leonor, the Holy House of Mercy or Santa

(28) . - Manuel Coelho Veloso "Noticia Historica da Meza da Conciencia e Ordens. Offerecida á real magestade, e augusto monarca portugues rey, e senhor nosso D. Joam 5."', in Biblioteca Nacional de Lisboa, Fundo Geral, Codex 10,887, p. 12.

(29). - "Regimento da Meza da Conciencia e Ordeins", in Biblioteca Nacional de Lisboa, Reservados, Codex 251.

(30). - Lázaro Leitão Aranha, "Meza da Consciencia Decretos, rezoluções de Consultas e Assentos della Desde a sua creação athe o anno de 1726 Com o Indes das Materias em que ha Provisões da Meza. Recopilados e reduzidos a methodo e offercidos Ao Muito Alto, e poderoso Rey e Senhor D. João 5. "’", Biblioteca da Ajuda, 51-vi-52, p. 42.

(31). - lbid., p. 487. 
Casa da Misericórdia, destined to become the most ambitious and grandest charitable enterprise ever undertaken by a Portuguese corporation (32). The Lisbon House was the first of such houses that from about 1500 were founded everywhere in Portugal and the Portuguese world. In Brazil alone, some 300 were started during the Portuguese period (33). Generally speaking, the Lisbon establishment was the model after which the other houses were patterned, and the Lisbon statutes of 1618 were copied by important Misericórdias at home and abroad (34). On its level of operations, the Holy House was as uniquely Portuguese as the Board of Conscience. No Hispanic country or territory, in Europe as in the New World, had its counterpart, and there was nothing to compare with it in Great Britain, Ireland, or the colonies.

The brotherhood or confraternity of the Santa Casa da Misericórdia of Lisbon came into being on August 15, 1498 (35). At the beginning, the Brotherhood was composed of 100 brothers, half of them craftsmen, half nobles, men who chose membership as a means of personal sanctification. Later the membership was enlarged to 600 (36). The reason why so many Portuguese joined brotherhoods, the most characteristic form of pious associations and the most widespread during the Baroque period, were set down very simply in a document of the seventeenth century.

'Because it is not viable for all men to live in Convents and Monasteries in this life, for that reason, and in order to enable them to achieve, and reach salvation the Church of God provides this venerable, and Holy Way, and Custom of Confraternities, \& Brotherhoods" (37).

(32). - For a more detailed view in English of the Lisbon Misericórdia, see A. J. R. Russell-Wood, Fidalgos and philanthropists. The Santa Casa da Misericórdia of Bahia, 1550-1755 (Berkeley, 1968). The bibliography on the subject in Portuguese is very large. See Fernando da Silva Correia, Estudos sobre a história da assistência. Origens e Formação das Misericórdias Portuguesas (Lisboa, 1944), and by the same author, "Misericórdias", in Joel Serrão, ed., Dicionário de história de Portugal, III (Lisboa, 1968), 76-80.

(33). - Fernando da Silva Correia, "Misericórdias", loc. cit., p. 78.

(34) . - Frederico Augusto Pereira da Costa, Anais pernambucanos 1591-1634, II (Recife, 1952), 45.

(35). - Mário Carmona, O Hospital Real de Todos-os-Santos da Cidade de Lisboa (Lisboa, 1954), pp. 158-159. 582.

(36). - João Bautista de Castro, Mappa de Portugal, V (Lisboa, 1768),

(37). - "Compromisso da Irmandade de Nossa Senhora de Porta Coeli, e do gloriozo Sam Joam Baptista", without date and place, in Arquivo Histórico Militar, Lisbon, Divisão I, secção I, caixa 2. The statutes appear to be of the seventeenth century. 
According to an eighteenth century source, the purpose of the Brothers of Mercy was to succor the needy, marry orphans, cure the sick, support and visit poor widows, issue passports (cartas de guia) for pilgrims, bury the dead, defend and feed prisoners and free them from jail, accompany the condemned to the gallows, and practice every other work of charity and mercy (38). In addition, the Brothers were authorized to visit the sick and the imprisoned, attend to the needs of the proud poor, take up collections, receive alms and legacies, conciliate the estranged, and protect abandoned children, that is to say, material and spiritual assistance in the home and in jail but initially not hospital service (39). The Brotherhood built its own church in the cathedral parish of Lisbon and moved to it in 1534 (40). Here it remained until the earthquake of 1755 when it was forced to move to the Hermitage of Our Lady of the Olive Tree (41). In 1768, by grace of King Joseph I, it took possession of the former Jesuit complex of São Roque, where the Misericórdia, now secularized, still is (42).

As was the case with every organization of any consequence during Baroque days, the Lisbon Misericórdia lived from endowments, annuities, special grants, and fees that it charged under certain conditions for certain services. It was maintained essentially through private benefaction, as one may see at a glance by consulting any of the Great Registers that the Misericórdia at one time used to record what testators and others had left or given it, and for what purpose (43). In one such Register of 1762, the listing is in summary form, without indication of the actual sums available for budgetary purposes. Undoubtedly it served to remind the Superintendent and members of the Board of Guardians what their legal obligations were and how funds were earmarked for specific ends. The operation was indeed very personal, and legacies were accepted for such diverse purposes as dowries, oil for chapel lamps, and sweets for patients of the Royal Hospital.

The oldest benefactor of the Misericórdia was King Emmanuel I (1495-1521) who gave an endowment for dowries. His celebrated daughter, the Infanta Dona Maria, niece of the Emperor Charles V, the richest princess in Christendom, known for the brilliance of her

(38). - Castro, op. cit., V, 582-583.

(39). - Carmona, op. cit., p. 159.

(40). - Castro, op. cit., V, 581.

(41). - "Livro 39 de Matrimonios, 1765-1770", in Arquivo da Santa Casa da Misericórdia, Lisbon.

(42). - Ibid., fol. fol. 148.

(43). - "Livro novo para satisfação dos legados dos testadores", in Arquivo da Santa Casa da Misericórdia, Lisbon. The register is dated 1762. 
Renaissance court, frequented by scholars of both sexes who were fluent in Latin and Greek, gave the Misericórdia an endowment for dowries and clothing. His daughter-in-law, the future Queen Dona Catarina, left part of her estate for dowries. Queen Dona Maria Francisca of Savoy, wife of Dom Pedro II (1683-1706), endowed chapels in the Church of the Holy Crucifix. The King himself left endowments for three dowries of 50 mil réis each and to provide annuities for his servants. In 1762, seventy-two legacies were still being paid, for the most part to children of the provident King's help but also to a few of his original employees. The stipends were to former valets de chambre, grooms of the chamber, stable boys, equerries, bagpipers, doorkeepers, coachmen, chapel musicians, and the like.

The first impressive legacy of a non-royal source probably came in 1594, when Dona Simoa Godinha, a black Portuguese from the Island of São Tomé, having no legal heirs, left her fortune to the Santa Casa da Misericórdia, as she expressed it, for the benefit of her soul (44). Dona Simoa spent her years in opulent style in her Lisbon house at the Porta do Mar, a neighbor to the Counts of Linhares and Portalegre (45). She was a member of three confraternities, Poor Clerics, Immaculate Conception (in São João da Praça), and St. John the Evangelist (in the Church of St. John the Baptist) (46). Her late husband, Luís de Almeida, a Portuguese aristocrat, was buried in the chapel that the two had built in the Church of the Santa Casa, the same church that came down in the earthquake of 1755 , and there she would also lie until Judgment Day. Her father was buried in the Church of the Immaculate Conception on São Tomé (47). To carry out her testamentary wishes, she empowered the Board of Guardians to appoint the executors of her will "until the end of the world", preferably from among its own ranks, but in any case Old Christians, men of good lives and customs (48).

At the time of her death in 1594, Dona Simoa owned three plantations on the Rio do Ouro, a plantation on São Tomé inherited from her husband, a plantation of her own on the same island, 300 arrobas of sugar from the plantation belonging to Dona Isabel de Araújo (apparently on São Tomé), an additional $\mathbf{3 0 0}$ arrobas from the plan-

(44). - There is an eighteenth century certified copy of the will of Dona Simoa Godinha, dated Lisbon, March 24, 1594, in the Arquivo da Santa Casa da Misericórdia among its miscellaneous papers. Hereafter cited as Dona Simoa Godinha.

(45). - Dona Simoa Godinha.

(46). - Ibid.

(47). - lbid.

(48). - lbid. 
tation of Francisco Freire (very likely on São Tomé as well). She referred in her will to an entailed estate on her husband's side which had devolved upon her, but gave no particulars. She and her husband obviously belonged to that new class of Portuguese, black and white, that the imperial experience had enriched.

She declared without arrogance that she was to be buried with the honors that befitted a person "of my quality". It was her wish that sixty-six poor people with lighted tapers accompany her body to its final resting place. She provided endowments for masses in perpetuum for the repose of the souls of her father, mother, brother, grandfather, and an aunt Maria Godinha. She also provided amply for her many slaves. A mulatto girl got her freedom and a dowry of 50 mil réis. A black girl was manumitted and sent back to father, supposedly in Africa. She owned other black and mulatto slaves: Margarida, Marquesa, Heitor, Heitor's daughter, Paulo, João, Luís, Mariana, Madalena, Domingos, Jerónimo, Natália, Guiomar, Maria, and Branca. To some she gave outright freedom, to others conditional. A male slave was freed with the obligation of playing the bagpipes in her chapel from the first vespers of the Feast of the Holy Spirit to compline next day, and from the first vespers of Christmas to compline the next day. Another would be freed at the end of ten more years of service. Still another would remain in bondage during the lifetime of a specified person. She asked Lourença de Almeida to take Maria das Chagas, Madalena, and Maria da Conceição under her roof and to cherish them at the expense of her estate. Keep them, she implored Lourença, until

"my executors choose their state of life ... with great love and good treatment, as I did, mindful of the affection with which I for the love of God raised them, showering them with the kindness of deed and word".

She distributed her estate among a variety of works of mercy. The income from her property on São Tomé would be used by the Misericórdia for captive orphans and incurables and for other pious works. She left 300 arrobas of sugar to the Santa Casa da Misericórdia of São Tomé to marry orphans or for other charitable works at the discretion of the Board of Guardians. As regards her plantations, she wanted the number of slaves on each rigorously maintained at their present levels.

The income from her farm properties, together with the 10,000 cruzados owed to her by the successor to her husband's entailed estate, 
and whatever other real estate or monies she might possess, were to be invested in an interest-bearing endowment to produce between three and four hundred mil réis per year. The income from the first year would be used to ransom captives, young men, children, and women, and in their absence the most abandoned and cruelly treated. From the second year, to marry orphans with dowries of between 30 and 40 mil réis each. From the third, for the benefit of the incurables of the Hospital of St. Anne, "which is above my chapel", and if the income should be in excess of the needs, for the benefit of jailbirds. The three-year cycle was meant to be repeated forever. And finally, she charged the Santa Casa with the responsibility of looking after her chapel, keeping it in repair, decorated, favored, and reverenced.

Simoa Godinha's will was read in Lisbon on March 27, 1594, immediately after her death, and on that date the Misericórdia began to take possession of her estate. Her plantations in Africa continued to produce income for the Holy House for many years. There are records in the Customhouse of Lisbon to show that the Superintendent and Brothers of the Misericórdia were allowed to transport cargoes of sugar from the Godinha plantations on São Tomé in two English bottoms in 1647 and 1648 (49). Dowries from endowments left by Dona Simoa were paid by the Misericórdia as late as 1768 (50). And as late as 1830 the Infirmary of St. Anne received bolts of cloth from Simoa's estate for the clothing of its crippled patients (51).

A sizable number of bequests were made through the agency of the Misericórdia to hospitals, infirmaries, and the sick of Lisbon. Legacies for the Hospital for Incurables of Nossa Senhora do Amparo, the Infirmary of St. Anne of the Royal Hospital, the Infirmary of the

(49). - "Indice geral Dos Extractos que se tirarão e copiarão dos Livros do cartorio de Alfandega em que entra o da reformação dos Alphabetos dos primeiros seis Extractos das couzas mais consideraveis contheudas nos Alvaras Decretos Regimento \&. a insertos no livro chamado Novo e nas primeiras duas partes do livro 22 os quais se queimarão com os proprios Livros do Registo no Incendio que houve na dita Alfandega depois do Terremoto do primeiro de Novembro de 1755. Mandado fazer o dito Indice por ordem do Dezembargador Francisco Xavier Porcille cavaleiro professo na Ordem de Christo do Conselho de Sua Magestade conselheiro de sua real Fazenda e Administrador geral da dita Alfandega \&. Feito e dictado na forma da dita ordem por Jozeph de Seyxas e Vasconcellos cavaleiro professo na ordem de christo servidor da toalha de Sua Magestade e Escrivão da Meza grande do Despacho d'Alfandega mayor desta cidade e Reyno \&." Em Lisboa Anno de 1759", in Arquivo Geral da Alfândega de Lisboa, n. 115, letters $P$ through $V$, fol. 602 v. and 603 .

(50). - "Livro 39 de Matrimonios, 1765-1770", loc. cit., f. 157 v.

(51). - Dona Simoa Godinha. From a note attached to the will. 
Franciscan Fathers, the Infirmary of the Arrábida Fathers of St. Catherine (52). Dowries were a consistently popular form of charity. A dowry to be given on Christmas day. Dowries for the neediest girls. Other dowries from the estate of the Viceroy of India, Luís de Mendonça Furtado, Count of Lavradio. Diogo Caiado Rijo remembered orphans, the blind, and the crippled, and left dowries for them. Simão Cardozo endowed a dowry for members of his family who joined a religious community or a house of retirement. Dom João Cosme da Cunha, Cardinal of the Holy Roman Church, the celebrated creature of the Marquess of Pombal who at the end turned against his patron, endowed during his lifetime dowries of 100 mil réis each. There were even dowries for the foundlings of the Royal Hospital (53).

Legacies for pious works were also administered by the Santa Misericórdia. Legacies for specified chapels, such as chapels in the cemetery, the Church of St. Michael or the Church of the Incarnation. For masses, for oil, for sacred lamps, pensions for a wife or another member of the family or indeed a servant. The Misericórdia accepted bequests for religious purposes outside of Lisbon: chapels in Castelo Branco, Viana do Castelo, the Franciscan Convent of Torres. Vedras.

Simoa Godinha did not provide in her will for one of the most important works of mercy performed by the Misericórdia of Lisbon, the maintenance of facilities for foundlings, but the Board of Foundlings was happily remembered by other pious people. Besides legacies, the Board enjoyed a steady income from a variety of sources. Every year since 1637 the Board of Foundlings received annuities from the Senate of Lisbon, since 1688 from the Royal Tobacco Monopoly, since 1690 from the High Chancery of the Court and Realm, since 1710 from the Customhouse of Lisbon, since 1711 from the Overseas Council, since 1734 from the Council of the Exchequer, since 1744 from from the Receiver of Customs of Tomar. There were other annuities from the Royal Warehouses, the Mint, the Board of Conscience and Orders, the Tribunal of Accounts, the High Court of Lisbon, India House, Ceuta House, and from the administrators of the tax of one per cent on gold. The Board was further entitled, since 1758, to a fee paid by the contractors from all contracts awarded in public bidding (54). cit.

(52). - "Livro novo para satisfação dos legados dos testadores", loc.

(53). - "Livro Segundo dos asentos dos dottes do Emminentissimo Senhor Cardeal da Cunha principiado no anno de 1763", in Arquivo Histórico da Santa Casa da Misericórdia de Lisboa.

(54). - From an unclassified register in Arquivo Histórico da Santa Casa da Misericórdia de Lisboa listing the income of the Mesa dos Engeitados. 
Another source of income was from loans, usually at 5 per cent per annum, in keeping with the Church's stand on usury, which were placed by the Misericórdia for the benefit of the foundlings. The treasurer of the Misericórdia, Dom Francisco José de Almada, negotiated a loan from the Brotherhood that was scheduled to be paid in 1767. In 1718 and again in 1720 the Count of Unhão used a pension or tença that he had from the Customhouse of Lisbon as collateral for loans, a part of them at $61 / 4$ per cent. Unhão received still another loan in 1721. A 5 per cent loan was made to the Marquess of Castelo Melhor in 1723. In 1724 the governor of Minas Gerais, Dom Lourenço de Almeida, was lent money at 5 per cent per annum. When loans were not paid, the Misericórdia took defaulters to court, sometimes socially prominent defaulters, such as the Count of $\mathrm{Co}-$ culim and the Count of Soure.

The Board of Foundlings received some income from the rental of flats in Lisbon. Exceptionally, there were special gifts from important people. The Cardinal Patriarch of Lisbon gave a stipend every year. The Queen, beginning in 1766, paid the wages of three wet nurses in the Turn Room.

The Royal Foundling Home was operated by a senior staff made up of the Reverend Secretary, the Reverend Assistant to the Secretary, the Syndic of the Board, the Physician of the Home, the Surgeon, the Procurator and Collector of the Income of the Home, and the Collector of the Income of the Board. Children were received on the turn or delivered to the Home from other parts of the city. No child was refused, and all black children were raised as free persons. At one time the Home had separate registers for white and black children, but the distinction was abolished of May 1, 1834. On that day, Father Bernardino Pinto do Vale Peixoto, the baptismal chaplain of the Home, wrote the following note as the traditional monarchy of Dom Miguel I was in the throes of death:

"The Committee decided that the entry of blacks and Colored, onward from the first of May of the present year, be registered promiscuously in the book of the whites" (55).

When a child arrived, the normal procedure was to have it baptized immediately (unless there was a note on its person to indicate that this had already been done) and handed over to a wet nurse. The

(55). - "Livro 29 de Entradas e Baptismos dos Expostos Pretos, e Pardos", in Arquivo Histórico da Santa Casa da Misericórdia de Lisboa. 
child was, of course, entered in the appropriate register. Each entry was followed whenever possible by a comment, something to identify the child by. When the child died, there was a note to that effect. Generally speaking, children were placed on the turn or brought to the Home with certain identifying marks, such as a medal, scapular, ring, or ribbon. Sometimes a note was pinned to the child, indicating his age, name, and whether or not he had been baptized. Occasionally there was a note to say that the child would in time be claimed by the family. Negro and colored children were identified by the color of the skin: pretinho, mulatinho, pardinho, little black, little mulatto, little colored. When a child showed only a light touch of blackness, he was described as amulatadozinho. A record of these distinctive marks was of the utmost importance to the families that would later ask for their offspring.

The registers of the Foundling Home speak of the seamy side of life, of sin and poverty and degradation, but they also are redeeming by the depths they disclose of the human heart. In 1658 an English child by the name of Tomás was left at the door of the Home, apparently by someone no longer able to care for him while his mother lay on a sick bed in an infirmary of the Royal Hospital (56). In the same year a baptized boy abandoned by anonymous parents. The father was described as a soldier serving on the frontier in the war of liberation against Spain, the mother as having accompanied the father to the front. In 1660 a child was found at the entrance to the residence of the Marquess of Niza and brought to the Home. A baby girl came on the turn on September 5,1660, with a note to the effect that she would eventually be rescued by the person who abandoned her, that she be baptized with the name of Luisa de Portugal, and that she be treated well by her wet nurse (57). On September 18 the Foundling Home registered another baby girl who had came on the turn with a note. She was declared to be Maria da Conceição, baptized, very loving, the daughter of "good and very well known noble parents" who would in the course of time claim her and pay the costs of her upbringing. (In 1663 this child was in the custody of Captain Manoel de Sá de Meneses, a resident of São Roque) (58). On October 3, an unbaptized boy was received with a note in Latin. On December 13, a female child, with a note indicating that she had been baptized in extremis by a layman (59).

(56). - "Livro das entradas dos engeitados que vem pela roda, 1657-1661", in Arquivo Histórico da Santa Casa da Misericórdia de Lisboa.

(57). — Ibid., fol. $214 \mathrm{v}$.

(58). - Ibid., fol. 218.

(59). - lbid., fol. $234 \mathrm{v}$. 
Actually, quite a few of the children in the Royal Foundling Home were ultimately returned to parents or guardians.

"In this Royal Foundling Home, there was surrendered to Catarina Rosa, unmarried, who lives on Rua da Caridade, parish of St. Joseph, having proved that she was her mother, the child Eusébia Maria Galvoa, who entered on December 16, 1769 ... she was excused from paying for the child's rearing because her poverty was legally proved...".

Sometimes children were handed over to third parties who swore to deliver them to their parents. At other times the cost of raising a particular child was borne by a parent or guardian. Paulo Martins, a domestic in the employ of His Majesty, paid for the maintenance of his twin boys from 1783, when they entered the House, until 1787, when the last one died $(60)$. In addition to newly-born or very young children, the Home also took care of abandoned older children.

During the years 1780-1830, the Royal Foundling Home received 261 children who were registered as black, 519 as colored, 12 as appearing to be colored, 2 as appearing to be black, and 20, though listed in the same register, without any indication of color. Each child was assigned a wet nurse or ama who was paid by the Home for her services. Now and then an ama was listed as black but usually the amas of the black and colored children were white women, a few of them single women, most of them married, wives of day laborers, shoemakers, seamen, tailors, fishermen, and the like (61). Maria, colored, was received by the Royal Foundling Home on May 17, 1813, turned over to Ana Teodora, wife of Martins Barreto, day laborer. The child was brought back to the Home on July 24 and on the same day

"handed over to the piety of the Most Illustrious and Excellent Marchioness of Valença, Dona Maria José de Noronha" (62).

A black child, Joaquim da Natividade, entered on the turn on September 13, 1817, was assigned to a wet nurse, returned to the Home on July 24, 1821 and on that day

(60). - "L9 19 de filhos entregues a seos pais", in Arquivo Histórico da Santa Casa da Misericórdia de Lisboa, fol. 33, $73 \mathrm{v}$.

(61). - "LQ 1 Entradas de Pretos e Pardos", in Arquivo Histórico da Santa Casa da Misericórdia de Lisboa.

(62). - Ibid., fol. 275. 


\begin{abstract}
"handed over to the charity of the Most Excellent Sebastiâo Correia de Sá" (63).
\end{abstract}

There are numerous instances of black children with white wet nurses in an earlier register. Some of the amas lived in Lisbon and the Lisbon area but many more in other parts of the country, especially in the midlands, in or near Leiria, Alcobaça, Batalha, and Aljubarrota (64). One wet nurse from Charneca took possession of a black baby girl and kept her in her custody until she was 23 (65). Another took a boy who was thought to be colored, raised him for six years, and then asked to keep him "for the love of God". He was allowed to remain with the woman with the understanding that he would be able to learn a craft of his choice (66).

To take a child from the Royal Foundling Home, to accept custody of it, and to raise it in one's household or to have it raised with another family, without cost of any kind to the Home, was applauded as a meritorious work of mercy, and members of the nobility were in the habit of practicing this remarkable kind of charity. At least as early as 1777 , the Foundling Home kept a special register where it recorded the names and characteristics of the children handed over

"to diverse ladies of this Court, and other Persons, to have them reared, and educated at their expense, without cost to this Royal Home" (67).

From 1778 until 1842, when the register was closed, over 150 foundlings were placed in this way. Exceptionally, a child might be given to a waxchandler or a master barber, as happened in 1795 , but more generally children were taken to be raised by the higborn. In 1804 the Dowager Princess of Brazil and the Infanta Dona Mariana both took a six-month old baby girl. In 1823, Her Most Serene Highness, the Infanta Dona Ana de Jesus took Carlota Angélica, provided for her upbringing, and returned her in time to the custody of

(63). - Ibid., fol. $302 \mathrm{v}$.

(64).- "Livro 31 dos conhec [sic] das amas 1738-1739", in Arquivo Histórico da Santa Casa da Misericórdia de Lisboa, fol. 263.

(65). - Ibid., fol. 211.

(66). - "Livro Primeiro meninos, e meninas de secco 23 Abril 1768 21 Novembro 1771", in Arquivo Histórico da Santa Casa da Misericórdia de Lisboa, fol. $47 \mathrm{v}$.

(67). - "Livro dos Asentos dos Expostos, e Expostas, que se dão, e tem dado, de Janeiro de 1777 , a diversas senhoras desta Corte, e outras Pesoas, para as mandarem criar, e educar por sua conta, sem despeza alguma desta Real caza", in Arquivo Histórico da Santa Casa da Misericórdia de Lisboa. 
the Royal Foundling Home. When King Miguel I visited the Home on March 15,1830, he found the girl there, took pity on her, and sent her to live at the royal palace of Queluz. During the years 1837-1841, the same Infanta, sister of Dom Miguel and of the late Emperor of Brazil, took three other children. The most illustrious women of the realm emulated the charity of the royal persons. The Duchesses of Cadaval, Lafões, and Terceira; the Marchionesses of Penalva, Tancos, Alvito, Castelo-Melhor, Ponte de Lima, Niza, Louriçal, Angeja, Lavradio, Pombal, Abrantes, Valença, Borba; the Countesses of Vila Verde, Ribeira Grande, São Tiago, Lumiares, Calheta, Valadares, Vila Nova, Obidos, São Vicente, Redondo, Peniche, Vimieiro, Lousã, São Paio, Rio Maior, Resende, Ficalho, Alva, Póvoa; the Viscountess of Vila Nova da Cerveira; the Morgada of Oliveira. The extraordinary Viscountess of Vila Nova da Cerveira and two other members of her immediate family took 24 children in 1786, including a black baby.

The numbers of black children taken by the nobility of Portugal to be raised at their expense were very high. In addition to the Viscountess, black or colored babies were raised by the Marchioness of Niza (1767), the Countess of Vimieiro (1790), and D. Maria do Carmo Henriques de Melo (1803). The Viscountess took 11 more children in 1787, including Maria Bárbara, a black child, and 5 children in 1788, among them Marcos, a colored or pardo. In 1803 the Marchioness of Pombal took two black children. In the same year the Marchioness of Castelo-Melhor took Domingos José, described as seeming to be a mulatto. The Marchioness of Abrantes took two black children in 1806 and a third one in 1807. The Countess of Peniche took Gertrudes Magna, a parda, in 1807 . In 1810 D. Mariana Eduarda Pestana Pereira Lobo Guerreiro de Almeida took a one-year old black boy, António Francisco. In 1815, the Baroness of Manique took Maria, a black child.

There were entries with terse comments that explain why a particular child was chosen and what was in store for him. Most people took children simply "for the love of God", for the sake of Christian charity, to increase the treasury of merit in Heaven. The benefactor of a two-year old boy declared that he would be "fed, dressed, shod, and educated" at the expense of the foster parent and returned to the rightful parents if they should claim him. An entry on June 17, 1804 declared that

"the child Clara, black, was given to be raised by the charity of the Most Illustrious and Excellent D. Teresa de Lencastre".

In 1828, a domestic prelate of His Holiness, the Right Reverend Monsignor Francisco José Higino Franco, took the child Carlota, 
"to have her educated and instructed in the principles of Religion, and in everything else proper to her sex...".

Ten years later, in 1838 , she was returned to the Royal Foundling Home.

The care of abandoned children was not the only service the Santa Casa rendered the Africans; it also protected their freedom before the law. By the alvara of September 19,1761 and again by the aviso of January 7,1767 , the shipping or exporting of slaves to Portugal was prohibited, and a bond servant brought to Portugal with the intention of maintaining him in bondage could petition the Crown for a Certificate of Freedom. Moreover, any person who bought or sold a slave under these conditions was subject to the penalties imposed upon those who ran private jails and enslaved free men (68).

To what extent blacks brought to Portugal in contravention of the law appealed for help to the Misericórdia has not been determined. In a miscellaneous register of the eighteenth century, there are at least sixteen entries that record the names of blacks who were given Cartas de Liberdade or Certificates of Freedom. All were issued after the aviso of 1767 and all were signed by Diogo Inácio de Pina Manique, the celebrated Intendant-General of Police of the reign of Dona Maria I (69). One such certificate read as follows:

Sigifredo, a black from the Costa da Mina, who appears to be between 13 and 14 years of age, took advantage of the Protection of this Santa Casa da Misericórdia in order to assure his Freedom, said that he remembered being solemnly baptized in the Cathedral Church of the city of Bahia, with the said name, and that Manoel Lobato, a black man, had served as his godfather. He came to this city [of Lisbon] on the frigate of war "Our Lady of Grace", commanded by the Most Illustrious Most Excellent Dom Rodrigo Jozé de Menezes, having been brought from the said city of Bahia by the Revered Friar Manoel Lobato, a Franciscan, where he had bought him; and landing in this city in the month of October 1788 in Belém, he did not pass through the Customhouse. Whereupon, this Most Excellent Board, taking him under its Protection, as an abandoned person, favored him by certifying to the truth of the above, and by the Customhouse of

(68). - Borges Carneiro, op. cit., I, 102.

(69) . - "L० $1^{\circ}$ de filhos entregues a seos pais", in Arquivo Histórico da Santa Casa da Misericórdia de Lisboa, fol. $112 \mathrm{v}$. et seq. 
this City, and by the Superintendent of the same, Desembargador Diogo Ignacio de Pina Manique, Intendant-General of Police, the issuance of his Certificate of Freedom, signed by him, was ordered on August 13, 1789....

The Certificate, by means of which the law was carried out, was registered in the Customhouse and in the Misericórdia, ready to be appealed to whenever the occasion demanded.

Were the records of other blacks lost? Did they exist at all? Or does the fewness of the items indicate that the law was respected and that it had, in fact, put a stop to the importation of slaves? The answers are not easy to come by, but at least this much may be said: the Misericórdia remained true, in still another area of human and humane need, to the pious intentions of its founders.

The same kind of generous praise is due the Misericórdia for the dedication with which it performed the last of the seven corporal works of mercy, the burial of the dead. The body in life was the Temple of the Holy Spirit, the center of God's plan for the universe, and even though with death it returned to the dust out of which it had been fashioned, it remained venerable for the vessel that it had once been. Hence the emphasis on Christian burial.

The Misericórdia had a special responsibility in this connection to the poor and downtrodden and it practiced its charity impartially among the free and the slave, the black and the white, the native-born and the foreign-born. At the same time its services were available to persons of other social classes, the rich and the powerful and the socially prominent. Other brotherhoods could do the same thing, if they wished, and bury by way of example their own members, but not without paying a burial tax to the Misericórdia (70). This was stipulated at least as early as 1593, when the Cardinal Archduke of Austria, legate ad latere, bestowed upon the Lisbon Misericórdia the privilege of carrying the dead to the grave (71).

At one time the Misericórdia had three litters or tumbas that went about the city to pick up the dead, a more elegant one for those who could afford it, a more modest one for people who required a simpler funeral, and a plain one for the poor. The litters were in charge of men on the House's payroll who were prepared, at a call from a priest, to pick up a body and transport it to an indicated place of

(70). - Pereira da Costa, op. cit., II, 45.

(71). - Ibid. 
burial (72). The poor were generally buried in the Misericórdia's own cemetery, others in churchyards and churches, some in humble graves, others in expensive sepulchres, depending on the social position and the means of the deceased. As the Rector of the College of St. Patrick, that interesting Lisbon institution that had been established by Portuguese philanthropy during the height of the English persecution of the Irish to train priests for the Irish mission, once remarked, vanity was

"a vice as old as the world itself, and as universal as mankind, which follows [men] in life, and ordinarily does not abandon them in death" (73).

For slaves, at the bottom of the social scale, the Misericórdia also owned a rustic litter or esquife, and buried them, as it did the poor, in its cemetery.

The burial records of the Misericórdia from July 1764 through December 1767, here taken as a sample, show that a total of 2,372 persons were buried, among them 167 slaves (74). The entry for each corpse included whenever convenient or ascertainable the circumstances of death.

"Thomaz, single. a native of Sardinia, died in the residence of His Lordship the Count of Povolide, was brought to this Santa Casa, they said he was French, and no more was learned...".

Gregório Lopes, a black, arrested by order of Paulo de Carvalho, brother to the Marquess of Pombal, was listed as being

"so simple, that he was never able to say whether he was free or slave" and dying "in the infirmary of the galleys...".

(72). - Ibid., pp. 45-46. In 1551, the Misericórdia had a litter for the better class of people with fifteen men, ready to bury any one who requested the service. Another, smaller litter with four men made the rounds of the city every day to bury the poor. Cristóvão Rodrigues de Oliveira, Summario, em que brevemente se contem algumas cousas assim Ecclesiasticas, como Seculares, que ha na Cidade de Lisboa (Lisboa, 1755), p. 45. Oliveira's work was originally written in 1551 .

(73). - Manoel Cardozo, "The Internationalism of the Portuguese Enlightenment: The Role of the Estrangeirado, c. 1700-c. 1750", in A. Owen Ald idge, editor, The Ibero-American Enlightenment (Urbana, 1971), p. 205.

(74) - A burial register with the binder's title "Livro quarto que principia no Mez De Julho de 1764", in Arquivo Histórico da Santa Casa di Misericórdia de Lisboa. 
"Simăo Toledo de Almeida, captain of infantry, who said he was married to Dona Custódia Pais de Araújo, son of Florindo de Toledo, native of the city of São Paulo, State of America, died in the infirmary of Limoeiro Jail...".

When a heretic or an infidel was baptized in the Catholic faith, the fact was indicated on his record. Jorge Sticer,

"a German baptized on the fourth of the present month [of September 1764], died with all the Sacraments in the Royal College of Cathecumens, parish of Our Lady of the Incarnation, was buried in the cemetery".

Another entry referred to a man of the Moorish nation.

In a number of instances, the dying were brought to the entrance way of the Santa Casa itself and allowed to expire before they could identify themselves. There were references to "a black woman found dead on the Crossing of the parish of Our Lady of Perpetual Help", to the burial of an impoverished priest, to a man who had been knifed to death, to a Negress who fell dead on the Palace Yard, to a body found in the dump, to a foreign-born member of the Royal Guard, to gypsies, to many Spaniards, especially Galicians. to the dregs of the city, to the flotsam and jetsam of the Port of Lisbon, to the wretched and the poor who, no less than the fortunate, could die with the consolation that their bodies, thanks to the Misericórdia, would be given the decency of a Christian burial.

The charitable works performed by the Holy House of Mercy were rounded out most importantly by the Royal Hospital of All Saints. When the Misericórdia was founded in 1498, nursing facilities already existed in Lisbon, and the Misericórdia was not intended to care for the sick. It entered fortuitously into what we might call the hospital business, but by adding it to its roster of services it was able to conduct a more integrated operation. With the Hospital of All Saints, the Misericórdia could indeed lay claim to the practice of a complex of charities that in one way or another provided for the seven corporal acts of mercy.

The Royal Hospital of All Saints, located in the city of Lisbon on Rossio Square between Rua da Betesga and the Dominican Convent, and occupying before the earthquake and fire of 1755 an area that roughly corresponds to the present Praça da Figueira, was begun 
on May 15, 1492 by John II (75). Moved by the pious and Christian desire of giving

"the Poor, and paupers a more reliable place of refuge and remedy for their needs in this city than they have hitherto had" (76),

the King consolidated with papal approval the facilities and endowments of the existing hospitals in a new foundation, and, with a name that appropriately remembered the previous establishments, laid the cornerstone of the complex of structures that would finally be completed in 1502 by his brother-in-law and successor, the first Emmanuel, not inappropriately dubbed The Fortunate by his appreciative contemporaries.

At the beginning of the sixteenth century, the Hospital was the grandest facility of its kind in Portugal, one of the largest in the known world (77), and its activities were directed onward from 1504 by statutes or regimento of that year that would shape its development in the decades to come (78). The Hospital existed initially as an independent institution, protected by royal and pontifical patronage, with its own sources of income, as was customary, including endowments provided by the Crown and by private benefactors, a state of affairs that lasted until 1564. In that year the Hospital's administration was turned over to the Santa Casa da Misericórdia of Lisbon, under whose umbrella it remained for the remainder of the Baroque period. The Hospital did not lose by the earlier act its corporate identity, it continued visibly large in carrying out the corporal work of mercy for which it had been created, yet its activities and finances were thenceforth to be supervised by the Board of Guardians of the Holy House of Mercy (79).

(75). - Silva Correia, op. cit., devotes a chapter of his book to the Royal Hospital of All Saints. Sebastião Costa Santos has two works on the Royal Hospital, both published in Lisbon in 1925, $O$ início da Escola de Cirurgia do Hospital Real de Todos os Santos 1504-1565 and A Escola de Cirurgia do Hospital Real de Todos os Santos. Another important secondary source is by M. Ferreira de Mira, História da medicina portuguesa (Lisboa, 1948). There are other works.

(76). - Fernando da Silva Correia, ed., Regimento do Esprital de Todolos Santos de El-Rey Nosso Senhor de Lisboa Que deu El-Rey D. Manuel no Ano do Senhor de 1504 e que é pela primeira vez dado em livro (Lisboa, 1946), p. 17.

(77). - Ibid., p. 7.

(78). - Ibid.

(79). - Ferreira Mira, op. cit., p. 107. 
The Hospital was seriously damaged by fire on October 27, 1601, when its late Gothic church, facing Rossio Square, was destroyed (80). Rebuilt in the course of time, the church was destroyed again by fire on August 10,1750. The final disaster came on November 1, 1755, when the earthquake and fire of that memorable day made a shambles out of church and hospital (81). In a roundabout way, the Hospital managed to rise from its ashes, the result of the most scandalous act of the eighteenth century. When the Society of Jesus was banished from Portugal in 1759 and its properties were confiscated by the Crown, the spacious and magnificent buildings of the Jesuit College of Santo Antão, all of which, except for the imposing baroque collegiate church, survived the destructive fury of 1755 , were deeded by Joseph I to the Royal Hospital. Here, in these former Jesuit quarters, a citadel of nationalism in olden times against the hated Philips of Spain, the Hospital was reconstituted and revived, and out of respect for the King's munificence, became known as the Royal Hospital of St. Joseph. Today, Lisbon's most famous charity hospital is no longer royal, such a designation having come to an end with the monarchy in 1910 , but it retains the name of Joseph and continues to give life to the massive, scared buildings of the great Jesuit College. The seventeenth-century sacristy of the original church that was destroyed in 1755 , among the noblest of the existing interiors of Lisbon, with its ample chests of drawers for ecclesiastical vestments made out of hardwoods imported from Brazil, still stands, serving as the Hospital's chapel. It is no longer the heart of the Hospital, as its Catholic founders would have wished, but a witness nonetheless to the love of God among men, a charitable trust that has been kept alive, in a world of transitory splendors, for almost half a millenium.

The primitive buildings were in the form of a cross and comprised, in addition to three infirmaries - St. Vincent for fevers, St. Cosmas for the injured, and St. Claire for women - a number of private rooms, a hostel dedicated to Our Lady of the Forelorn, Nossa Senhora do Amparo, for pilgrims, beggars, and incurables, a foundling home, a refectory, kitchen, pharmacy, office, latrines, insane asylum, and other dependencies (82). The Hospital was maintained for Christians of the true faith, not heretics, schismatics, or infidels, foreign no less than national, black as well as white, slave and free, but only if you were poor and from Lisbon and could not otherwise take care of

(80): - Mário Carmona, O Hospital Real de Todos-os-Santos da Cidade de Lisboa (Lisboa, 1954), pp. 84-85. See also Castro, op. cit., V, 523.

(81). - Castro, op . cit., V, 523.

(82). - Silva Correia, op. cit., p. 7. 
yourself, or if you had become ill in, but were not a native of, the outlying areas, within 10 leagues of the city (83).

At admission time, a chaplain told the patient what the requirements were. If he did not confess his sins within the first two days of his stay, receive the sacraments, and write out his will, he would not receive "more charity, nor any alms whatsoever", nor would he "be housed any longer" (84). It was made clear to him that

"the first obligation of this hospital is to cure first The Souls of the sick who come to it rather than the ills of the flesh..." (85).

The Superintendent or Provedor of the Hospital was enjoined to protect the health of the patients by keeping the infirmaries scrubbed and clean, and to provide the nurses on occasion with

"some good odorants, as much as he thought might be needed, to give the said Infirmaries a good smell at all times, and the sick by this means comfort and satisfaction" (86).

The slaves of the Hospital were bound to keep the bedpans "very clean at all times", and the "necessaries" of the Hospital thoroughly washed once a week in the winter, maintain them clean-smelling, and twice a week during the summer (87).

The infirmaries (whose number increased as the need arose) were for the most part named after patron saints, the male apartments bearing the names of male saints, the female of female saints. In 1695 , the infirmaries for patients suffering from "fevers" were called St. Cosmas, St . Damian, St . Lawrence, St. Peter, St . Bernard, St . Vincent, St. Francis, St. Francis Xavier, St. Claire, Franciscan Fathers. The infirmaries for the injured, St. Dominic, St. Cajetan, and St. Catherine. St. John's Infirmary was for the male insane; St. Anne's, the female. St. Anthony's was for men suffering from venereal diseases and from wounds; St. Mary Magdalene, for women suffering the plagues of Venus. St. Elizabeth's, for women suffering from

(83). - Ibid., p. 41 .

(84). - Ibid., pp. 31-32.

(85). - Statutes of the chapel, May 19, 1602, in Registo Geral, vol. I, 1501-1606, in Arquivo do Hospital de São José, no. 640, fol. 412 v.

(86). - Silva Correia, op. cit., p. 39.

(87). - Silva Correia, op. cit., p. 71. 
diarrhea and consumption; St. George's, for men. St. Joseph's Infirmary was for convalescents (88).

The Royal Hospital, though it was founded as a charity hospital, also accepted paying patients, persons of the better classes who wished to cure themselves, or their slaves and servants, at their expense in the Hospital's infirmaries. The daily rate of 200 réis included food, medical and surgical care, bloodletters, medicines, and clothing. The rate was the same for all infirmaries, but the Hospital learned from experience that the cost of treating venereal diseases was much greater than that of fevers (89).

There was no segregation of patients within an infirmary, and certainly none on the basis of race or nationality. During 1685-1686, 119 women were admitted to the Infirmary of St. Claire, all indigents. One, admitted on May 29, 1685, was identified as an Englishwoman. Another Englishwoman, the widow of Cristóvão Espelho, i.e. Christopher Glass, was admitted in 1686. (It should be recalled that Lisbon was for many years a haven for Englishmen fleeing from persecution at home). There were at least two other foreigners in the infirmary at the same time, both natives of Spain (89a), and no less than 23 black and colored women. Some were listed as slaves, others as ireedmen, still others simply as blacks (90). In the Infirmary of St. Bernard, the records of patients admitted during the year 1659-1669 show, in a random sampling, that among the sick were Pedro de Morais, the slave of Maria Nunes; Luís de Meneses, the slave of the Countess of Ericeira; Cristóvão, a black man, native of Brazil, sentenced to the galleys; a Genoese; a Frenchman; and Castilians. The overwhelming number of men were listed as unmarried (91). The perennial presence of the foreign-born ought to be pointed out for the significance that it has. It is a reflection of the status that Lisbon then enjoyed as a bustling international city where jobs were plentiful and foreigners anxious to fill them.

The population of the Hospital was on occasion too large for the facilities. In 1551, the Hospital's 103 beds were not always enough to

(88). - "Livro III. Do registo dos papeis do Hospital Real de Todos of Santos. Anno de 1695", in Arquivo Histórico do Hospital de São José, fol. 64. From the memorandum of the Board of Guardians of the Misericórdia, Lisbon, January $25,1715$.

(89). - "Livro da Emfermaria de Santa Clara que comessa em 8 de maio de 685", in Arquivo Histórico do Hospital de São José, n. 1415.

(89a). .- Ibid.

(90). - Ibid.

(91) . - Entrada de Doentes do Hospital, Arquivo Histórico do Hospital de São José, no. 1410. 
treat the sick, and sometimes two patients had to share the same bed (92). As the decades passed by and economic life changed, more and more people flocked to the Hospital. In 1601 the Hospital had beds for 324 patients (93). From November 1, 1616 to November 1 of the iollowing year, 3,026 patients were admitted to the various infirmaries. Of their number, 620 died. In 1620 there were 600 patients at one ume in the Hospital and 200 foundlings (94). A report of 1752, pointing up the financial stringencies of the Hospital, declared that in a six-month period there were over 800 patients, days when the number almost reached $1,000(95)$.

When the Hospital began, it had two surgeons on its staff, one of whom lived on the premises, and a physician. They were required to visit the patients twice a day, once at daybreak and again before two o'clock in the afternoon, accompanied on their rounds by the Superintendent, Controller, the Chief Infirmarian, and the Druggist (96). New patients were received daily at $6 \mathrm{a} . \mathrm{m}$. in the winter and $7 \mathrm{a} . \mathrm{m}$. in the summer, at the Board of Waters, so called because urine analyses were performed there. After confessing his sins to a hospital chaplain and receiving the sacraments, the newly processed patient was taken by an infirmarian of his sex - there were 24 for men on or about 1594, an unspecified number of sister infirmarians for women - to his assigned place. The regulations called for beds made with "washed and clean clothes". No new patient would be put to bed without first being undressed by the infirmarian, his feet scrubbed, his hair trimmed, his beard trimmed or shaved, his nails cut, and "whatever else" the man might need. In any event, a patient had to be readied for bed "with much cleanliness" (97). When death occurred, patients were at once put into a shroud and taken from the infirmaries

"in such a manner as not to be seen by the other patients, because of the commotion that seeing them may cause..." (98).

(92). - Ferreira Mira, op. cit., p. 98.

(93). - lbid.

(94). - Carmona, op. cit., p. 238.

(95). - Report of the Syndic of the Royal Hospital, the Chief Huntsman of the Realm concurring, Lisbon, October 5, 1752, Arquivo Histórico do Hospital de São José, Codex 942, fol. 281 v.

(96). - Ferreira Mira, op. cit., p. 98.

(97) . - From the undated "Regimento dos Irmãos Obregões", found among papers of 1594, in Registo Geral, vol. 1, 1501-1606, in Arquivo Histórico do Hospital de São José, no. 640, fol. 366 v. et seq.

(98). - Ibid. 
The infirmarians were obliged to bury the bodies on the day of death (99). The Hospital maintained its own cemetery. In the eighteenth century it was located in the parish of Nossa Senhora da Pena, next to the chapel or ermida of Our Lady of Salvation (100).

The spiritual ministry of the Royal Hospital, as set down in the statutes or regimento of the chapel of 1602 (101), was in charge of a pastor, assisted by a coadjutor priest. Among the duties of the pastor was writing the last wills and testaments of the patients. Attached to the chapel were priest chaplains, men carefully selected, among other qualifications, for the beauty of their voices and knowledge of singing

("... this house is Royal and it is proper that the divine services celebrated in it be offered with all possible solemnity...").

The chapelmaster was required

"to be present in choir during the canonical hours and sung masses celebrated in the said chapel, leading both plainchant and descant...".

Other members of the chapel staff included a choir prompter, a master of ceremonies, a treasurer, a chapel steward or mordomo, acolytes, and organist. The organist had

"to play at all masses of the day and on Sundays, and holy days of obligation, as well as on the first and second vespers of all saints of double class, and on the Saturdays and octaves and complines of Lent, and on the matins and resurrection of Easter and on Ascension Day and on the so-called counted matins...".

The carelessness of the secular clergy entrusted with the Hospital's spiritual ministry led the Board of Guardians as early as the seventeenth century to toy with the idea of having them replaced with regular or order priests, men generally held to be more dedicated and less worldly. The Hospital's clergy, most of them with fixed stipends and therefore less amenable to control, were often so involved with their own affairs that many patients died without spiritual assistance. This was an intolerable situation to a Board that took seriously its

$$
\begin{aligned}
& \text { (99). - Ibid. } \\
& \text { (100). - Castro, op. cit., V, 671. } \\
& \text { (101). - Regimento da capella, doc. cit. }
\end{aligned}
$$


responsibility of providing spiritual guidance and consolation to the terminally ill along the way to Heaven (102).

By a special order of August 30,1737, signed by members of the Board of Guardians of the Hospital, Viscont Tomás da Silva Teles, then serving as Superintendent, new and more explicit instructions were given for the direction of the Hospital's spiritual ministry (103). There had been complaints about the lack of dedication on the part of the staff of the Hospital Church, the cavalier attitude toward the dying and the dead, that obviously called for remedial action. The order of 1737 was meant to put a stop to the abuses.

By virtue of this order, the pastor of the Hospital would thenceforth take the Sacred Viaticum to the sick before the physicians made their calls. The coadiutor priest would administer the rite with the customary cope and humeral veil. The Latin master would not be paid unless he appeared daily for the class that he was supposed to conduct for the acolytes, the chapelmaster unless he taught them solmization every day.

The acolytes in turn were expected to arrive promptly at stated hours to help at mass and carry out their other obligations, especially the accompanying of the dead to the cemetery whenever necessary, mornings as well as afternoons, bearing the cross and lanterns. During prayers, they were admonished to stand by in the choir. They were advised to attend their classes every day, be obedient to their teachers, and pay the other chaplains "every attention and courtesy".

The Father Treasurer would accompany the litter to and from the cemetery, even a second time if necessary, when there were more bodies than the litter could conveniently take and had to come back to the Hospital for those that may have been left behind. The Board insisted that the litter be accompanied at all times by a priest, to make sure that no body would be deprived at the graveside of the prayers of commendation of the soul. The Father Treasurer would also be obliged to accompany the Sacred Viaticum whenever it was administered, one week by the pastor, one week by his coadjutor. With both priests, his presence was "equally necessary, and convenient".

(102). - Registo Geral do Hospital de Todos os Santos, 1603-1697, in Arquivo Histórico do Hospital de São José, no. 941, fol. 67.

(103). - "Regimento de huma ordem da Meza para se observar o que nella se conthem", Lisboa, August 30, 1737, in "Livro III. Do registo dos papeis do Hospital Real de Todos os Santos. Anno de 1695", Arquivo Histórico do Hospital de São José, no. 942, fol. 202. 
In a further effort to improve the Royal Hospital's spiritual assistance, the Misericórdia on June 28, 1739 added four agonizant chaplains to the authorized staff (104). The new priests were to be men of good habits and known charity, with faculties to say mass and hear the confessions of both men and women. Confessing the patients would continue to be the business of the pastor and his coadjutor, but the agonizants would be pressed into service whenever the demands were beyond the ability of the two top priests to handle.

The purpose of a more effective ministry continued to be the same as always: to make sure that the sick,

"who come to cure themselves in the infirmaries of the Royal Hospital are treated not only with all the necessary care and charity for the betterment of their complaints and illnesses, but also with all piety and zeal for the salvation of their souls, this being the end toward the achievement of which every diligence should be employed..." (105).

Two more priest confessors, their salaries to be paid by the Royal Exchequer, were added to the staff of the Hospital by King John V on March 3, 1745. His Majesty's

"innate and royal piety, and charitable zeal for the spiritual welfare of his sick vassals"

in the Royal Hospital led him to authorize the expansion of the religious ministry, hopeful that by this means the patients of the Hospital would find "proportionate means" to achieve the health of the soul, which was, in John's opinion, (106).

"more estimable and important than that of the body..."

A highlight of the religious pageantry of the eighteenth century was without doubt the week-long festivities of 1747 , celebrated by express royal command and at royal expense to commemorate the

(104). - Ibid.

(105). - "Regimento que a mesa da Misericórdia mandou fazer para os 4 capelães agonizantes do Hospital Real", Lisboa, June 28, 1739, in "Livro III", cited above, Arquivo Histórico do Hospital de São José, fol. 216 v. et seq.

(106). - lbid. 
canonization in 1746 of St. Camillus of Lellis, the Italian founder of the Ministers of the Sick, an order of priests and clerks regular dedicated to the care of the sick in hospitals that dated from 1582 (107). For eight days there were special ceremonies in the Hospital Church, with "admirable music" and homilies by "learned and elegant" orators. The interior of the Church was decorated with such success

"that up to the present time, nothing richer or more delightful has been achieved...".

And on every night of the octave

"not only was all the Hospital illuminated but all the façade of the Church, forming delicious patterns for the eyes...".

The last day of the octave, on June 25,1747 , the function was brought to a glittering close

"with a grand procession led by a precious standard carried by a Priest of the religion of St. Camillus, ... wearing a surplice, and he was accompanied at the four leadings by four titled persons of this Court who were the Most Illustrious and Excellent Marquess Chief Steward [of the Royal Household], then serving as Superintendent of the Misericórdia, and the Most Illustrious and Excellent Marquess of Angeja, the present Treasurer and Chief Infirmarian of the said Hospital, together with the Count of Tarouca and the Count of Atouguia, and ... bringing up the rear of this procession a precious bier with the statue of St. Camillus of Lellis, borne by the Prelates of the religious communities that came to take part in the feasts, and because the bier had ten holds, two grave Priests of the Board of the Poor Reverend Clerics of this Hospital were asked to join, and two grave Priests of the religion of St. Dominic, the bier as it moved being surrounded by twelve silver lanterns carried by the reverend priests of the said brotherhood of Poor Clerics, and behind the bier the Most Illustrious and Excellent Archbishop of I.acedemonia in pontifical vestments who appeared on the last day of the feast as a Member of the said Brotherhood; and the Chaplain Priests of this Church with the acolytes were also incorporated in the Brotherhood of the Poor Clerics ... taking part in this function all the Infantry and Cavalry, by order of His Majesty, which

(107). - "Livro III", cited above, fol. 261 v. 
occupied all of Rossio Square, and surrounded all the streets over which the procession, which left from the Church of the Hospital, moved; and went along Rua dos Escudeiros to the Rua dos Odreiros, and marching round the Square, returned to the said Church...".

The income of the Royal Hospital of All Saints came from endowments and inheritances, from fees charged private patients, including their servants and slaves, and at one time from theatricals and a lottery. An early document makes clear that the Hospital by royal grace was entitled at one time to receive certain property or perquisites in the Cape Verde Islands and in Upper Guinea. On October 11, 1545, the Superintendent of the Hospital authorized Afonso Vaz, bailiff or feitor of the Hospital, to visit the Cape Verdes to collect "the things" that belonged to the Hospital. A specific duty was to collect what was owed to the Hospital from the estates of Portuguese castaways in Guinea, living and dead, and to sue them or their heirs in the event of non-payment. The instructions pointed out that

\footnotetext{
"mulattoes, children of the white men who go about as castaways in Guinea",
}

had been declared slaves of the Hospital. Theses half-breeds should be contacted and encouraged to settle among Christians. Each halfbreed agreeing to do so, and paying a fee of 2,000 reais to the Hospital, would be given a Certificate of Freedom. Such Certificates of Manumission would also be issued, in return for the same contribution to the Hospital, to any son or daughter of a deceased castaway (108).

The Hospital enjoyed a number of prayer endowments which provided for the maintenance of the mercieiras who lived on the premises of the Hospital, women of good repute who discharged certain religious obligations, such as assisting at mass and offering up the pious act for the souls of stated benefactors (109). Dona Inês de Ávila left a legacy to the Misericórdia to buy sweets for the inmates of the Royal Hospital. It had been her life-long custom to distribute them among the patients on the feasts of Our Lady, and by her legacy provided for the continuance beyond the grave of her lovely work of

(108). - "Treslado do Regimento que Afonso Vaz feitor do esprital que hora vai para a Ilha do Cabo Verde", October 11, 1545, in Registo Geral, I, Arquivo Histórico do Hospital de São José, no. 640, fol. 187 et seq.

(109). - Das entradas dos expostos, 350 to 525, in Arquivo Histórico da Santa Casa da Misericórdia de Lisboa. 
mercy (110). Other people left bequests to one of the dependencies of the Hospital, such as the House or Hospital of Nossa Senhora do Amparo for Incurables. This was the case, as we have seen, of Dona Simoa Godinha, the Lisbon Negress of great wealth and position who died in 1594.

In 1730, António Francisco Fialho, a business man of Lisbon, owner of a merchant ship, left bequests to the Royal Hospital, the foundlings of the Hospital, and the poor of the Hospital of Nossa Senhora do Amparo (111). Another business man, João de Morais Rego, with extensive commercial dealings in Bahia, Rio de Janeiro, Pernambuco, Viana do Castelo, Rotterdam, and England, remembered the foundlings of the Royal Hospital in his will of November 18, 1699 (112). Dona Joana Batista, wife of Francisco Pinheiro, another prominent business man, also remembered the Hospital in her will of April 11, 1736 (113). A sampling of benefactors, in brief, that does no more than suggest the nature and variety of the bequests.

Gifts from the living were another source of income or profit to the Hospital. There is a record of the slave that by his personal alvará of November 4, 1740, the Duke of Aveiro gave the Hospital. He was identified as a black by the name of Benedito and was donated with the understanding that he would be used in the service of the sick and would never be sold or removed from the premises (114). The Hospital was authorized to promote a raffle or lottery by royal provision of May 13,1740, on the grounds that, on the one hand, the number of sick "both nationals and foreigners" had increased, and, on the other, the income of the Hospital had been adversely affected by the

"notorious sterility of the lands of the floodplain [of the Tagus River]".

(110). - From an affidavit by the Count of São Lourenço, scrivener of the Board of Guardians of the Santa Casa da Misericórdia de Lisboa, October 12,1750 , in "Livro III", above cited, fol. $270 \mathrm{v}$.

(111). - Will of April 16, 1730, in Registo Geral de Testamentos, Livro 200, Arquivo Nacional da Torre do Tombo, fol. $167 \mathrm{v}$. et seq.

(112) . - Will of November 18,1699, in Registo Geral de Testamentos, Livro 90, Arquivo Nacional da Torre do Tombo.

(113) . - Will of April 11, 1736, in "Documentos diversos relativos ao Hospital 1575 a 1749 numero 1", Arquivo Histórico do Hospital de São José, no. 1139 , fol. 81 et seq. See also Nuno Daupias d'Alcochete, "Esboço de catálogo do Arquivo Histórico do Hospital de São José", Boletim Clínico dos Hospitais Civis de Lisboa, nos. 1-2 (1965), 286.

(114). - "Livro III", cited above, fol. 232. 
To meet its financial needs, the Hospital was permitted to sell chances at 50 réis each for prizes worth between 20 and 40 mil réis and make an estimated profit of 20 per cent (115).

The Hospital also benefited from the monopoly it enjoyed for a long period of time of the Lisbon stage, and in a special way from the leasing of the city's most famous playhouse, the Páteo das Comédias, where there were boxes set aside for the nobility (116). The Hospital hardly played a nationalistic role in the history of the Portuguese theatre because the plays at the Páteo das Comédias were generally in Castilian and by Castilian actors (117). But the arrangement permitted the Hospital to carry out its mission more effectively, and misery, needless to say, has no national or cultural boundaries.

The Hospital's connection with the theatre begins at least as early as 1588, when King Philip I gave the Royal Hospital for a fixed period of years an absolute monopoly of the theatre in Lisbon, by virtue of which "comedies" could not be staged, in public or in private, in quarters other than those permitted by the Superintendent and officials of the Hospital, a profitable privilege that was successively renewed. In 1595 Philip renewed it again, for an additional two years, with the proviso that the plays be first approved by the Crown, to protect "the good customs of the commonwealth" from "indecent" and "prejudicial" works, and that the income derived from this source be spent for the benefit of the sick

"who are being cared for in the said Hospital" (118).

The same privilege was confirmed by Philip's successor by royal letter of April 9,1603, again with a restriction, that males would play male roles, females female roles. This suggests that men impersonated women, and the King, by his action, put a stop to the "inconveniences" that might result from the practice (119). The concession was renewed

(115). - Provisão, Lisbon, May 13, 1740, in "Livro III", cited above, fol. 230 .

(116). - Petition of António de Azevedo, Lisbon, July 16, 1615, in Registo Geral do Hospital de Todos os Santos, 1603-1697, Arquivo Histórico do Hospital de São José, no. 941, fol. 87 v.

(117). - Ibid.

(118) . - The King to the Marquess Viceroy, Valladolid, April 9, 1603, in Registo Geral do Hospital Real de Todos os Santos, I, 1501-1606, Arquivo Histórico do Hospital de São José, no. 640, fol. 425.

(119) - - Alvará, Lisbon, December 11, 1612, in Registo Geral do Hospital Real de Todos os Santos, 1603.1697, Arquivo Histórico do Hospital de São José, no. 941 , fol. 76 . 
still another time by the alvará of December 1612, which further provided for automatic extensions at the King's pleasure.

In 1613 the Hospital, with the authorization of the Crown, leased the Páteo das Comédias to an impresario, Dona Catarina do Carvajal, who received, in return for 60 per cent of the receipts, the exclusive right of staging plays in the Hospital's Páteo (120). Subsequently, when the facility was destroyed by fire, the Hospital purchased the land and subrogation from the heirs to whom both belonged, and constructed a new and costly theatre on the site, where comedies were once again performed for the financial benefit of the Hospital.

In 1727 complaints were lodged against the operation on the grounds that it was hardly becoming to the Misericórdia (as administrator of the Hospital), devoted as it was to pious and holy works, to occupy itself with comedies and comedians. Whereupon King John V directed the Treasurer of the Hospital and the Board of Guardians of the Misericórdia "totally to abstain from this employment". By virtue of this decision, the Hospital was deprived of the beneficial use of the theatre that it had reconstructed at great expense and obliged to assume, as a consequence, the cost of the two chapels of daily masses that it had agreed to pay when it acquired the property. By 1735 the Hospital's privilege was so openly flaunted that an Italian opera company, without the permission of the Hospital, rented quarters and presented its wares to the public. In the following year another Italian company came to Lisbon, again renting quarters and presenting its operas without the approval of the Hospital (121).

This was the state of affairs when the Crown reversed itself and in 1737 allowed the Superintendent and Brothers of the Santa Misericórdia, as administrators of the Royal Hospital, to lease their Páteo das Comédias to an impresario for 12 years at the rate of a conto per year with the exclusive right to put on plays and operas in Lisbon, provided that they themselves had no direct connection with so demeaning a business. Other companies soon began to circumvent the Hospital's privilege by presenting operas, not with live figures but with puppets. The Misericórdia once again appealed to the Crown for protection, and once again, in 1738, the Hospital's monopoly was affirmed, this time to include puppets as well (122).

(120). - Alvará of King John V, Lisbon, June 29, 1737, in "Livro III", cited above, fol. 199 et seq.

(121). - Ibid.

(122). - "Registo de huma Provizão de Sua Magestade pella qual ordena, e manda o mesmo Senhor que sem licença do Hospital se năo fação reprezentações com figuras arteficiaes senão nos lugares, que pello mesmo Hospital the forem assinalados, na mesma forma que as comedias, e operas", in "Livro III", cited above, fol. 209 et seq. 
The interest of King John V in protecting the Royal Hospital speaks well of his concern for the poor and underprivileged. The death of the sovereign whose lavish benefactions were proverbial did not affect the situation of the Hospital. As the Syndic of the Royal Hospital wrote in 1752, with the concurrence of the Principal Huntsman of the Realm, the Hospital of Lisbon was under "royal protection" because the poor, having been made in the image and likeness of Christ Our Lord, were entitled to be provided for in their adversity. Princes everywhere, Catholic as well as infidel, had for this reason founded hospitals. Infidel princes did not do it through Jesus Christ, Our Lord, but they were nonetheless solicitous of the welfare of the commonwealth, whose object is of course the preservation of its vassals. And preservation is an arduous thing, for

"a man is not made in less than twenty-five years" (123).

In the process of providing the citizens of Lisbon, and especially the poor, with a number of basic material needs, the Santa Casa da Misericórdia never failed to win the admiration of natives and foreigners alike. An aura of fame for a job well done accompanied it in history. Its presence, felt in innumerable ways, in a city of many facets once described as "the world itself on a small scale", was the logical extension, on the practical level, of the faith of a people whose devotion to "our sacred Religon" was matched only by their piety. Protected over the years by kings and commoners, developing as it lived the extensive services that it eventually offered, the Holy House was the grandest charitable creation of the Portuguese of the Old Regime. It was already a surpassingly successful operation in 1619, when João Baptista Lavanha, the chronicler of the realm, extolled the virtues of the brotherhood whose dedication had made it possible.

This Brotherhood is called of Mercy because the Brothers who belong to it practice and dedicate themselves to their seven corporal works and to their two hospitals, one for the lame, one for incurables, and with great charity, spending therewith great sums of money in these sainted works, income accruing in part from endowments established by the Kings, Queens, and Princes of Portugal, and by devout private persons, which each year amounts to almost 30,000 cruzados, and in part from generous alms which in this year of 1619 will amount to more than 10,000

(123). - Report of the Syndic of the Royal Hospital, October 5, 1752, doc. cit., fol. 282 . 
cruzados, the whole of it spent in marrying 66 maidens with a total of 7,756 cruzados in dowries; in ransoming captives with the 10,425 cruzados that were turned over to the Superintendency of Captives and to the friars of the Holy Trinity; in supporting abandoned children, 700 cruzados; in maintaining the two Hospitals, 1,708 cruzados; in helping impoverished jailbirds, 6,300 cruzados. Nine thousand four hundred cruzados were distributed among the poor in asylums and needy persons of honorable state; 1,540 cadavers were buried with shrouds, many of them for the love of God; 34,000 masses were said, part of them with alms from private persons, and part as obligations assumed by the Brotherhood, not counting the Anniversaries instituted for the souls of the benefactors of this holy house, for which ministrations it has 22 Chaplains who pray the Canonical hours in choir, with very good music. This Brotherhood also subsidizes the House of Retirement for maidens, which exists in Lishon, 13 of them together with 5 servants, and some of them will marry this year and leave, and other maidens will take their place. This Brotherhood likewise is in charge of the Royal Hospital of All Saints, founded by King John II with great magnificence and wealth. All kinds of illnesses are treated in it, with care, cleanliness, and satisfaction, and the Hospital is attended with charity by more than 160 Brothers who are rotated every month in the infirmaries (124).

This unique institution, so proudly and justly praised by Lavanha, devoted to the practice of works of mercy, and the like of which was unknown in all of Europe, was a mirror in which was reflected the baroque conscience of the Portuguese.

MANOEL DA SILVEIRA CARDOZO, natural da tha do Pico, Açores, nasceu em 1911 e emigrou para a Califórnia na companhia de pessoas de sua família em 1915. Formado pela Stanford University em 1931, ali se doutorou em 1939. A tese de doutoramento versou sobre a história da mineração no Brasil até 1750. Nomeado diretor da Biblioteca Oliveira Lima em 1940

(124). - João Baptista Lavanha, Viagem da catholica real magestade del rey D. Filipe II. n. S. ao reyno de Portvgal E rellação do solene recebimento que nelle se the fez (Madrid, 1622), fol. 61 et verso. 
e professor catedrático de história da Universidade Católica da América, Washington, D. C., em 1954. Foi durante 10 anos chefe do Departamento de História da mesma Universidade. E antigo presidente da Associação Católica Americana de História, bolseiro do Instituto de Alta Cultura, Fundação Calouste Gulbenkian, e Departamento de Estado. Condecorado duas vezes pelo Brasil, uma pela Santa Sé. E autor de inúmeras monografias (além de outros trabalhos) sobre história luso-brasileira, publicadas nos Estados Unidos, no Brasil, em Portugal, em Espanha, no México e na Venezuela. Traduziu para o inglês uma antologia de poesia brasileira (1922-1972), para comemorar a Semana de Arte Moderna de São Paulo. E sócio de institutos de cultura no Brasil, nos Açores, em Lisboa, no Perú e nos Estados Unidos. Está a tratar agora da comemoraçăo da presença dos portugueses nos Estados Unidos para o bi-centenário nacional de 1976. Para os seus estudos históricos, tem trabalhado nas bibliotecas e arquivos de Portugal, de Espanha, Vaticano, França, Inglaterra, Estados Unidos, México, Argentina, e Brasil. Já foi presidente do Committee on Brazilian Studies da American Historical Association. E antigo colaborador do Handbook of Latin American Studies. Colabora na World Book Encyclopedia e na Encyclopedia Britannica. Serviu de sub-secretário-geral do Primeiro Colóquio Internacional de Estudos Luso-Brasileiros.

Washington, D. C., 1 de Julho de 1974. 